\title{
SPECTRUM OF CAUSATIVELY RELEVANT AEROALLERGENS OF SOUTHERN UKRAINE WHICH PROVOKE ALLERGIC REACTION IN PATIENTS WITH POLLINOSIS ON THE EXAMPLE OF KHERSON REGION
}

DOI: 10.36740/WLek202104117

\author{
Anastasiia V. Myrhorod, Valentyna I. Velychko, Viktoriia Y. Nakhashova \\ ODESSA NATIONAL MEDICAL UNIVERSITY, ODESA, UKRAINE
}

\begin{abstract}
The aim: the analysis of spectrum of causatively relevant aeroallergens of southern Ukraine which provoke allergic reaction in patients with pollinosis. Materials and methods: ambulatory medical records data and skin prick-testing results of 477 patients afflicted with pollinosis in Kherson ( 250 women - 52,41 \% and 227 men $-47,59 \%)$ aged from 19 to 66 years old $(38,05 \pm 0,45)$ have been analyzed retrospectively.

Results: all patients revealed clinical implications mainly during the September-0ctober period. Clinically 151 patients (31,66\%) showed severe and $326(68,34 \%)$ moderate to severe clinical progression. Composite family plants (composites) proved to be the most widespread plants (69,76\%) among all pollen aeroallergens of Kherson region. Weeds and sunflower showed the highest percentage among composites: Ambrosia topped to 79,87\%, Helianthus (sunflower)-75,68\%, Artemisia - 42,98\%, and Cyclachaena (sump weed) $-36,48 \%$. Wild and cultivated grains' aeroallergens toped to $28,22 \%$. Among them the sensibility to Lolium perenne (19,28 \%), Festuca pratensis (17,82 \%), Dactylis glomerata $(17,82 \%)$ has been noticed more often. Tree aeroallergens topped to $2,03 \%$.

Conclusions: The third wave of pollen formation (September-0ctober period) appeared to be the most significant and clinically hard for Kherson region. According to the specific allergologic research data, allergens of the composite family plants, among which pollen of Ambrosia, Helianthus, Artemisia and Cyclachaena cause more frequent sensibility, turned to be the most widespread causatively relevant aeroallergens in Kherson region which provoke allergic reaction in patients with pollinosis. The second place was taken by wild and cultivated grains' aeroallergens, among which sensibility to Lolium perenne, Festuca pratensis, Dactylis glomerata proved to be the most common.
\end{abstract}

KEY WORDS: pollinosis, spectrum of aeroallergens, composite family plants, southern Ukraine

Wiad Lek. 2021;74(4):902-905

\section{INTRODUCTION}

Allergic disorders (AD) are a serious prevalence cause in all world and a significant problem to health care system in general, both for the developed and yet developing countries. At least $30 \%$ of the world population and $80 \%$ of families are suffering from $\mathrm{AD}[1]$.

In recent decades the number of patients with $\mathrm{AD}$ nearly doubled, and according to the World Health Organization forecast, in 30 years the majority of Earth population will be suffering from allergy.

For now, one of the most widespread $\mathrm{AD}$ is pollinosis. Frequency of its prevalence ranges from 1 to $40 \%[2,3]$. Pollinosis is characterized by seasonal occurrence, variety of clinical implications, possible polyvalent allergy and food sensibility development, that complicate diagnostics and treatment of this pathology. Pollinosis symptoms are caused by general inflammatory changes of mucous coats, first of all, eyes and airways, and can significantly influence patients' lives. Clinically pollinosis occurs in the form of rhinoallergosis or rhinoconjuctivitis (to $95 \%$ [4]), and atopic asthma.

Pollinosis peculiarities depend on a variety of factors, first of all on climate-geographically and ecologically related ones. Every region has its own distinctive spectrum of allergen plants and pollen formation calendar, in connection to that the course of disease might vary within one country or even region.

Therefore, three main periods of pollen formation are relevant for our country: spring period (April-May), summer period (June-July) and summer-autumn period (July-September). Also three main groups of plants-allergens are singled out: trees, grains and composites, the majority of which are weeds. For the first (spring) period pollen formation of trees is typical (birch, oak, alder, linden, ash, poplar, elm, acacia, willow and others). The second (summer) period is characterized by pollen formation in wild and cultivated grains (rye, corn, Poa pratensis, Phleum pratense, Festuca pratensis, Dactylis glomerata, wheat-grass (Agropyron), Bromus, Lolium perenne and others). Considering the third (summer-autumn) period, pollen formation in composites (Ambrosia, Artemisia, Chenopodium, Helianthus, Cyclachaena and others) is common.

At the present moment there exist some scientific works on spectrum of aeroallergens study for certain regions. For instance, aerobiological researches distinguishing in 
Table I. The results of specific allergologic examination by method of skin prick-testing with pollen allergens in patients with pollinosis of Kherson town, number of patients $n=477$

\begin{tabular}{|c|c|c|c|c|c|}
\hline \multicolumn{2}{|c|}{ Trees } & \multicolumn{2}{|c|}{ Grains } & \multicolumn{2}{|c|}{ Composites } \\
\hline Allergen & $\begin{array}{l}\text { Abs. number } \\
\text { (\%) }\end{array}$ & Allergen & Abs. number (\%) & Allergen & $\begin{array}{l}\text { Abs. number } \\
\text { (\%) }\end{array}$ \\
\hline Acacia & $9(1,89)$ & Dactylis glomerata & $85(17,82)$ & Ambrosia & $381(79,87)$ \\
\hline Walnut & $14(2,94)$ & Rye & $56(11,74)$ & Chenopodium & $28(5,87)$ \\
\hline European alder & 0 & Alopecurus pratensis & $16(3,35)$ & Artemisia & $205(42,98)$ \\
\hline Linden & $5(1,05)$ & Festuca pratensis & $85(17,82)$ & Cyclachaena & $174(36,48)$ \\
\hline Poplar & $5(1,05)$ & Zea mays (corn) & $55(11,53)$ & Helianthus & $361(75,68)$ \\
\hline Birch & 0 & Lolium perenne & $92(19,28)$ & Dandelion & $19(3,98)$ \\
\hline Oak & 0 & Agropyron repens & $33(6,92)$ & - & 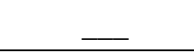 \\
\hline European hornbeam & 0 & Bromus erectus & $3(0,62)$ & - & 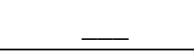 \\
\hline Chestnut & 0 & Phleum pratense & $34(7,13)$ & - & - \\
\hline Sugar maple & 0 & Poa pratensis & $6(1,26)$ & - & $\underline{-}$ \\
\hline
\end{tabular}

Table II. Classification of pollen allergens revealed in patients examined according to pollen allergens groups

\begin{tabular}{cccc}
\hline Pollen Allergens Group & $\begin{array}{c}\text { Trees, } \\
\mathbf{n}(\%)\end{array}$ & $\begin{array}{c}\text { Grains, } \\
\mathbf{n}(\%)\end{array}$ & $\begin{array}{c}\text { Composites, } \\
\mathbf{n}(\%)\end{array}$ \\
\hline Total number of positive results $n=1646$ & $33(2,03)$ & $465(28,23)$ & $1149(69,76)$ \\
\hline
\end{tabular}

methods and time have been carried out in many cities such as Kyiv, Vinnytsia, Zaporizhzhia, Lviv, Odesa, Poltava, Donetsk, Dnipro and Simferopil. Aeropolynological monitoring procedures are being constantly held in Vinnytsia, Lviv, Zaporizhzhia [5].

But despite this, there is relatively little information regarding spectrum of aeroallergens of southern Ukraine among patients afflicted with pollinosis. Moreover, no similar research was carried out in Kherson region before. Thus, our aim was to explore spectrum of causatively relevant aeroallergens analyzing the results of specific allergologic examination based on skin prick-testing method among patients afflicted with pollinosis in Kherson.

\section{THE AIM}

The aim was the analysis of spectrum of causatively relevant aeroallergens of southern Ukraine which provoke allergic reaction in patients with pollinosis.

\section{MATERIALS AND METHODS}

In hindsight, we researched the data of ambulatory medical records and results of skin testing with allergens of 477 patients who applied to town allergology centre based on Kherson Town Clinical Hospital n.a. Ye.Ye. Karabelesh during the period of 2012 to 2019 years. A specific allergologic examination has been carried out by the method of skin prick-testing with allergens of Ukrainian production (Vinnytsia, LLC "Imunolog"). Established allergens of trees, composite family plants and grains, as well as domestic allergens (acarids Dermatophagoides farinae and Dermatophagoides pteronyssinus, pillow feathers, epi- dermal agents) were used. Patients' examination was done during the remission period (the end of October-April). Entry criteria resulted in making pollinosis diagnosis in patients above 18 years old. Entry criteria: infant age, negative results of skin prick-testing. Statistic data estimation was performed with the help of Microsoft Office Excel 2010.

\section{RESULTS}

In the whole, ambulatory medical records and the results of skin prick-testing with of 477 patients: 250 women $(52,41 \%)$ and 227 men (47,59\%) aged from 19 to 66 years old.

The average age of examined patients was $38,05 \pm 0,45$.

All the examined patients had symptoms of pollinosis in anamnesis and revealed clinical implications mainly during the period from August to September.

Monovalent allergy, in other words sensibility to only one aeroallergen, was discovered only in 7,59 \% patients (36 examined). The majority of patients had a polyvalent sensibility to more than one aeroallergen - 92,4\% (441 patient). Among them 106 patients $(22,22 \%)$ except sensibility to pollen aeroallergens, had also sensibility to domestic and/or epidermal ones (i. e. had a secondary diagnosis of annual rhinoallergosis).

Clinically, 151 patients $(31,66 \%)$ had severe and 326 $(68,34 \%)$ moderate to severe disease progression.

The results are included in the tables 1,2 .

Among pollen aeroallergens of Kherson region, the most widespread ones are composites (69,76\%).

Among composites the greatest percentage showed weeds and sunflower: Ambrosia - 79,87 \%, Helianthus (sunflower) - 75,68\%, Artemisia - 42,98 \%, and Cyclachaena (sump weed) $-36,48 \%$. Aeroallergens of wild 


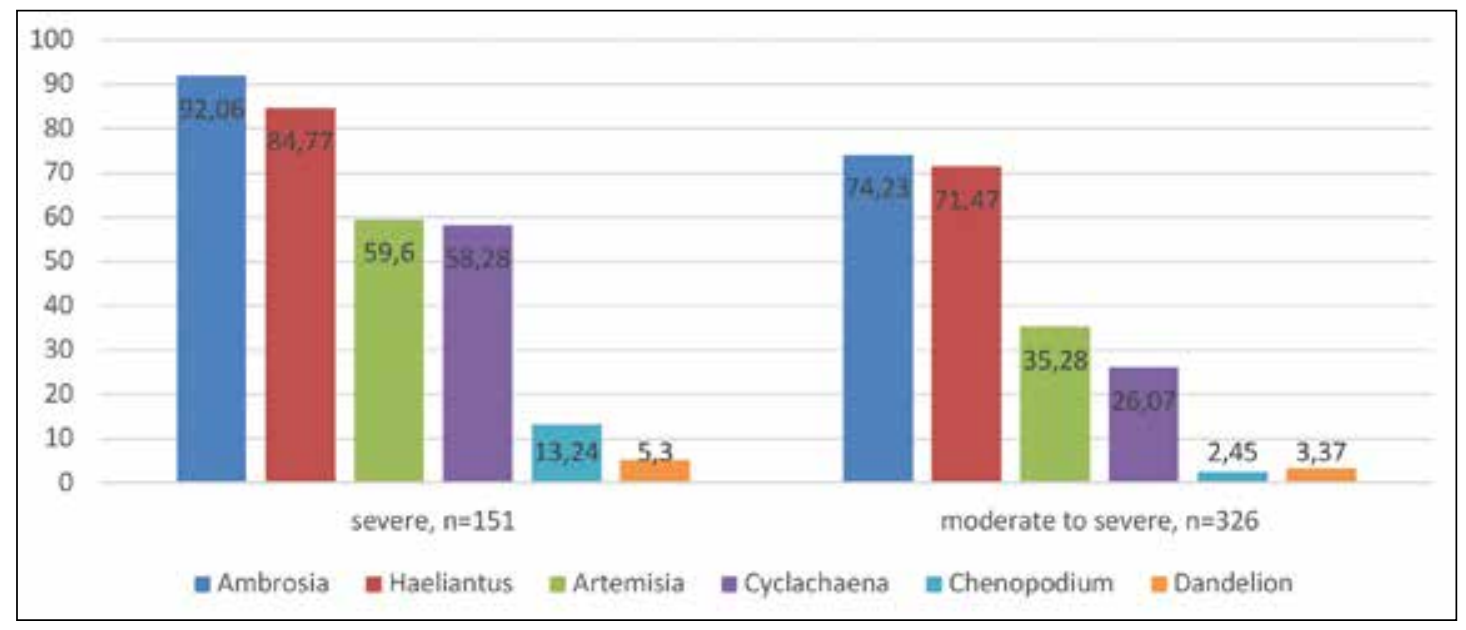

Fig. 1. Positive results of skin prick-testing compared to composites' allergens in patients with severe and moderate to severe clinical progression.

and cultivated corn plants were estimated in $28,22 \%$. The most frequent sensibility among them was noticed to Lolium perenne (19,28\%), Festuca pratensis $(17,82 \%)$, Dactylis glomerata $(17,82 \%)$. Aeroallergens of trees registered only $2,03 \%$.

\section{DISCUSSION}

The average age of examined patients was $38,05 \pm 0,45$ that confirms data of dominating disease incidence among people of young, able to work age [6].

The most widespread pollen aeroallergens of Kherson region are composites $(69,76 \%)$, that proves the similarity of spectrum of causatively relevant aeroallergens with other region of southern Ukraine, particularly Odesa, Zaporizhzhia, Dnipro regions and Temporarily Occupied Territory of Crimea $[7,8,9,10]$. However, received data greatly differ from the spectrum of other regions of our country (for example, in Vinnytsia and Lviv regions trees took the first place, in Kyiv region - grains $[4,11,12]$.

One might assume that received relatively large amount of positive results of skin prick-testing with composites' allergens comparing to trees' and grains' allergens is connected to the fact that allergens of the first ones are the most widespread and aggressive in our region. It is also proved by that the majority of patients with severe clinical progression revealed positive skin prick-testing results with composites' aeroallergens comparing to the patients with moderate to severe clinical progression (Pic.1). Number of pollen allergens, before which the results had been positive, also proves the complexity. Among the patients with severe clinical progression this number was estimated in $5 \pm 0,17$ and appeared to be credibly higher $(\mathrm{p} \leq 0,01)$ than among the patients with moderate to severe clinical progression $(2,7 \pm 0,08)$.

\section{CONCLUSIONS}

1. For Kherson region the third wave of pollen formation is the most typical and clinically hard (August-September period) - almost all patients examined reveal exacerbation during the indicated period and positive results of skin prick-testing with plants-allergens producing pollen in this time period.

2. The most widespread causatively relevant aeroallergens in Kherson region in patients with pollinosis according to the data of specific allergologic research proved to be allergens of composites (69,76\%), among which the most frequent is sensibility to pollen of Ambrosia, Helianthus, Artemisia and Cyclachaena.

3. The second place is taken by aeroallergens of wild and cultivated grains $(28,23 \%)$, among which the most frequent is sensibility to pollen of Lolium perenne, Festuca pratensis, Dactylis glomerata.

4. The complexity of clinical progression in patients afflicted with pollinosis is caused by number of pollen allergens sensibility proved (difference is credibly higher in patients with severe clinical progression comparing to moderate to severe one $(\mathrm{p} \leq 0,01))$.

5. The subject of spectrum of causatively relevant aeroallergens investigation and analysis of southern Ukraine, particularly Kherson region, claims further research. The result that is to be expected is pollinosis diagnostics and treatment optimization and prevention of food sensibility development in such patients considering regional peculiarities of pollen formation in plants-allergens.

\section{REFERENCES}

1. Sanchez-Borges M., Martin B.L., Muraro A.M. et al. The importance of allergic disease in public health: an iCAALL statement. World Allergy Organization Journal. 2018/ https://doi.org/10.1186/s40413-0180187-2.

2. Pukhlyk B.M., Pollinos [Pollinosis]. Monography.2017; 60. (In Russian).

3. Horiachkina L.A., Drobik 0.S., Nasunova A.Yu. Pollinosy: sovremenniy vzgliad na problem. [Pollinosis diseases: contemporary look at the problem]. Newsletter of Family Medicine. 2012; (1):10-16. (In Russian).

4. Klymenko V.A. Regionarni osoblyvosti pylkovoi sensybilizatsii (za danymy Oblasnogo dytiachogo alergotsentru). [Regional peculiarities of pollen sensibility (in accordance with the data of Regional child allergocentre]. Clinical immunology. Allergology. Infectology. Special issue: Allergic diseases in clinical practice. 2012; 66-67. (In Ukrainian). 
5. Rodinkova V.V. Osnovnyi aeropalinologichnyi spektr mist tsentralnoi, pivdennoi ta shidnoi Ukrainy. [ Basic aeropalinologic spectrum of cities in central, southern and eastern Ukraine]. Biology and medicine achievements. 2013;(2):11-15. (In Ukrainian).

6. Brożek J.L., Bousquet J., Agache I. et al. Allergic Rhinitis and its Impact on Asthma (ARIA) 2016. Allergy Clin Immunol. 2017;140(4):950-958.

7. Dytiatkovska Ye. M. Osoblyvosti sensybilisatsii u khvorykh na polinos v m. Dnipropetrovsku. [ Sensibility peculiarities in patients afflicted with pollinosis in Dnipropetrovsk city]. Rhinology. 2011; 2: 17-20. (In Ukrainian).

8. Tolstanov A.K., Harmider O.V., Hozhenko A.I. Osobennostizabolevaemosti i klinicheskaia kharakteristika bolnykh pollinozom v g.0dessa. [Disease incidence peculiarities and clinical characteristics of patients afflicted with pollinosis in 0dessa city]. Topical issues of transport medicine. 2013;4(34):60-68. (In Russian).

9. Malieieva H.Yu., Prykhodko 0.B. Dynamika palinatsii ambrozii v Zaporizhzhi v period iz 2012 po 2016 rik. [Palination dynamics of ambrosia in Zaporizhzhia during 2012-2016 period]. Newsletter of Zaporizhzhia National University. 2016;2:121-129. (In Ukrainian).

10. Znamenska L.K. Spektr prichinnoznachimykh allergenov, vyzyvaiushchikh pollinoz u zhytelei Simferopolia. [Spectrum of causatively relevant aeroallergens which provoke pollinosis in citizens of Simferopol]. Tavrichesk medicine-biological newsletter. 2013;4(64):6064. (In Russian).

11. Besh L.V., Novikevych S.Z., Zadvorna 0.I. et al. Dynamika struktury sensybilizatsii do pylku sered dytiachogo naselennia Lvivskoi oblasti protiagom 20-richnogo sposterezhennia. [Dynamics of structure of sensibility to pollen among infant population of Lviv region during 20 years observation period]. Child's health. 2014;7(58):37-42. (In Ukrainian).
12. Zaikov S.V., Hatska D.0., Korytska I.V. Spektr sensybilizatsii do allergeniv u ditei ta molodi Vinnytskoi oblastiz respiratornoiu alergiieiu. [ Spectrum of sensibility to allergens among children and youth with respiratory allergy in Vinnytsia region]. Asthma and allergy. 2016;4:25-28. (In Ukrainian).

\section{ORCID and contributionship:}

Anastasiia V. Myrhorod: 0000-0001-8094-5693 A,B,C,D,E

Valentyna I. Velychko: 0000-0003-3607-0265

Viktoriia Y. Nakhashova: 0000-0003-1891-6984 ${ }^{F}$

\section{Conflict of interest:}

The Authors declare no conflict of interest.

\section{CORRESPONDING AUTHOR Anastasiia V. Myrhorod \\ Odessa National Medical University \\ 2 Valykhovskyi prov., 65000 Odesa, Ukraine \\ tel: +380991572250 \\ e-mail: nastya.krysenk01404@gmail.com}

Received: 11.11 .2020

Accepted: 02.03.2021

A - Work concept and design, B - Data collection and analysis, C - Responsibility for statistical analysis, D-Writing the article, $\mathbf{E}-$ Critical review, $\mathbf{F}-$ Final approval of the article 